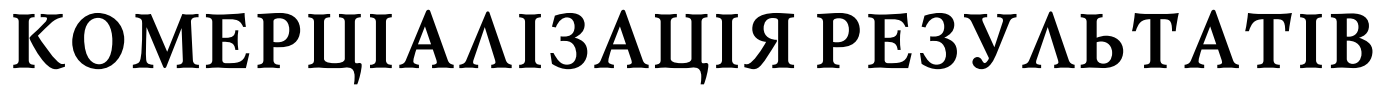 ГОСПОААРСЬКОÏ АІЯ $Ь$ ВОСТI В РІЗНИХ BИААХ ТОРГIВ $\Lambda$
}

\author{
O. Yevtushevska, \\ $\mathrm{PhD}$ in Economics, Lecturer of the Department of Enterprise, Taras Shevchenko National University of Kyiv
}

\section{COMMERCIALIZATION OF PRODUCTION IN DIFFERENT TYPES OF TRADE}

Визначено особливості комерціалізації продукції в різних видах торгівлі, зокрема у легальній та несанкціонованій торговельній діяльності. Висвітлено окремі причини виникнення неконтрольованої торгівлі. Основними причинами розвиткустихійної комерціїє соціально-економічна нестабільність, недосконала фіскальна політика та до певної міри правовий нігілізм. Розкрито переваги та недоліки окремих видів несанкціонованої торгівлі. До недоліків можна віднести ухилення від сплати податків, потенційну небезпеку для здоров'я споживачів через порушення санітарно-гігієнічних норм, перекриття проходів і шляхів евакуації, забруднення вулиць, неврегульованість трудових взаємин. До переваг відносимо пом'якшення суспільної напруженості, створення робочих місць, формування особливої культури спілкування. Охарактеризовано окремі інструменти комерціалізації продукції в різних видах торгівлі. Сформульовано основні принципи комерціалізації товарів в умовах стихійної торгівлі, зокрема до них належать підтримка позитивної репутації продавця, вміння співпрацювати з конкурентами, встановлення гнучких цін на продукцію тощо.

Peculiarities of commercialization in different types of trade are shown, namely in legal and illegal commerce. Main reasons of an uncontrolled trade are lightened. Social and economic instability, unsuccessful fiscal policy, legal nihilism cause unguided trade. Advantages and disadvantages of some types of uncontrolled trade are shown. In our opinion, main drawbacks of unguided commerce are evasion income taxes, breaking of sanitary-and-hygienic standards, choking up of some urban streets, uncontrolled working relations. But such trade also has its advantages, namely softening of social contradictions, working places creation and a special communication culture. Some people come to unguided markets not only to buy something, but also to communicate and to bargain. Some instruments of commercialization in different types of trade are characterized. Legal commerce allows use wider range of various methods, such as advertising, neuro marketing, brands and trademarks etc. Commercialization of production in unguided trade usually concentrated on verbal advertising, promotional inscriptions, on simple manipulations (some sellers use them). On the uncontrolled markets products often are considered to be natural and healthy ones. Of course, it is not always true. In our opinion, main drawback of such unguided trade is possible breaking of sanitary norms. Main principles of products commercialization in uncontrolled trade are lightened. Positive reputation of tradesman, ability to collaborate with competitors, flexible prices and occasional use of manipulations became informal rules of commercialization under such specific conditions. Legal trade gives wider range of commercialization methods, but some of them can be ineffective, because of organizing mistakes and insufficient market analysis. To our mind, nowadays the most effective 
ways of commercialization under legal trade are guerrilla marketing and significant brand. As to traditional advertising it can gives rather discordant effect. Most producers try to use suitable distribution channels and make their goods accessible for potential consumers.

Ключові слоВа: неконтрольоВана торгіВля, комерціалізація, партизанський маркетинг, мотиВаційні наnuсu, penymauiя.

Key words: uncontrolled trade, commercialization, guerrilla marketing, promotional inscriptions, reputation.

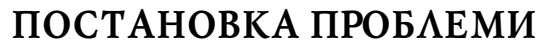

Особливості комерціалізації продукції залежать від багатьох чинників, у тому числі і від виду торгівлі, зокрема у даній статті нас цікавитиме процес комерціалізації товарів і послуг як у легальній, так і в нелегальній торговельній діяльності. Останнє явище є менш дослідженим, проте також становить науковий інтерес. Під нелегальною торгівлею тут розуміємо лише стихійну, "базарну" торгівлю та діяльність несанкціонованих малих архітектурних форм. Оскільки поняття "нелегальна торгівля" включає в себе і цілковито аморальні та суспільно-руйнівні види діяльності.

Соціально-економічна нестабільність, недосконала фріскальна політика та до певної міри правовий нігілізм призвели до активного розвитку неконтрольованої торгівлі в Україні. Неконтрольована торгівля $€$ незаконною, дехто вважає ії̈ виключно негативним соціальним явищем. На нашу думку, таку діяльність швидше можна назвати суперечливим проявом слабкої економіки. Такий тип торгівлі - це закономірний результат прорахунків у державному регулюванні економічної сфери. Методи комерціалізації продукції в умовах неконтрольованої торгівлі подекуди мало відрізняються від методів застосовуваних у законній торговельній діяльності, але все ж існують відмінності.

\section{АНА $І 3$ ОСТАНHIX АОС IАЖЕНЬ ТА ПУБАІКАЦІЙ}

Увага вітчизняних та іноземних науковців зосереджена, передусім, на процесі комерціалізації новітніх розробок. Зокрема, дослідженням комерціалізації продукції, а саме інноваційних товарів займаються: Ф. Котлер, Г. Армстронг, Р. Голідей, С. Годін, С. Грінгард та інші. Серед українських учених проблемою комерціалізації новітніх технологій цікавляться: І.І. Вещицька, Н.А. Чугрій, М.П. Бутко, М.П. Калиниченко, Р.С. Косцик, Р.М. Крамаренко та інші. На жаль, питання комерціалізації традиційної продукції не є достатньо дослідженим, зокрема процес реалізації товарів у різних видах торгівлі, в тому числі в несанкціонованій торговельній діяльності, потребує більш глибокого та всебічного дослідження.

\section{META CTATTI}

Метою статті $є$ дослідження комерціалізації результатів господарської діяльності в різних видах торгівлі для розкриття як прийнятних, так і маніпулятивних прийомів реалізації продукції. Завданнями статті $\epsilon$ висвітлення особливостей комерціалізації продукції в різних видах торгівлі; визначення переваг і недоліків окремих видів несанкціонованої торгівлі, характеристика принципів комерціалізації товарів і послуг в умовах стихійної торговельної діяльності, дослідження процесу комерціалізації в торговельних точках.

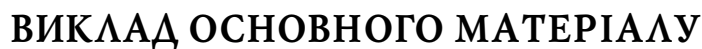 АОС $\triangle$ IАЖЕНHЯ}

Несанкціонована торгівля вважається негативним соціальним явищем. Крім того, як зазначалось вище, ця діяльність $€$ незаконною. Все ж, на нашу думку, неконтрольована торгівля (мається на увазі стихійна, "базарна" торгівля та діяльність незаконних малих архітектурних форм) не $\epsilon$ однозначною. Вона спровокована низкою причин і не може бути подолана лише за допомогою гасел і закликів. До недоліків такого виду торгівлі можна віднести: ухилення від сплати податків, потенційна небезпека для здоров'я споживачів через порушення санітарно-гігієнічних норм, перекриття проходів і шляхів евакуації, забруднення вулиць, неврегульованість трудових відносин (якщо такі виникають). До переваг стихійної торгівлі належать: пом'якшення суспільної напруженості, створення робочих місць, фрормування особливої культури спілкування. Останнє часто не враховується критиками. Частина споживачів йде на стихійні базари не тільки за покупками, але й за емоціями та спілкуванням. Фактично, тут перетинаються два способи життя - міський і сільський. Саме в умовах стихійної торгівлі виникають неформальні принципи взаємодії різних учасників ринку. Санкціонована торгівля, зокрема реалізація продукції через торговельні мережі, здебільшого, $є$ знеособленою. Вона передбачає не стільки взаємодію між людьми, скільки відточування маркетингових прийомів для підвищення попиту на продукцію.

Неконтрольовану торгівлю можна поділити на стихійну, яка характеризується надзвичайною гнучкістю і мобільністю, та стаціонарну. Зокрема стихійну торговельну діяльність уособлюють комерсанти, які можуть швидко змінювати локацію, торгують нерегулярно, адаптуються до адміністративнихобмежень. Стаціонарна торгівля представлена несанкціонованими малими архітектурними фрормами. Як зазначалось вище, особливості комерціалізації продукції залежать від виду торгівлі. Зокрема стаціонарна торгівля використовує деякі методи комерціалізації, характерні для легальної торговельної діяльності. Наприклад, мерчандайзинг, сутність якого, на думку Страшинської Л.В., "полягає у кращому представлені (презентації) товарів у торговельному підприємстві, а його основна мета - забезпечення максимальної присутності продукції компанії в торговельній точці й досягнення максимальної її оглядовості (можливості потрапляння в поле зору споживача)" [1, с. 286]. Безумовно, торгівля у невеликих несанкціонованих точках не дає можливості використати всі інструменти мерчандайзингу. Крім того, власники малих архітектурних фрорм інколи припускаються помилок, які знижують рівень попиту на їхню продукцію. До найбільш поширених належать: цінники, які перекривають товари; нечітко написані ціни, що змушує потенційних покупців постійно перепитувати; відсутність місця, щоб поставити речі; плутанина у викладці цінників. Загалом, стаціонарна нелегальна торгівля не може бути зразком використання мерчандайзингу, оскільки сам її характер пе- 
редбачає тимчасовість і обмеженість. Натомість у цій ссрері часто використовуються мотиваційні написи, які покликані заохотити не просто до одноразової купівлі, а й до повторних покупок. Найчастіше такі написи апелюють до почуття гумору або до альтруїстичних почуттів. Фактично ці написи $€$ проявом так званого партизанського маркетингу, який за словами Свічкарь В.А. та Чорномурової В.Ю., "є малобюджетним способом реклами й маркетингу, що дозволяють ефективно просувати свій товар або послугу, залучати нових клієнтів і збільшувати свій прибуток, не вкладаючи або майже не вкладаючи грошей" [2]. В умовах обмеженості бюджету використання вивісок і правильно підібраних шрисртів також може сприяти комерціалізації продукції. Так, застосування яскравих кольорів під час оформлення торговельної точки, охайний вигляд, грамотні написи, ввічливість допомагають реалізовувати товар. Безумовно, потенційні споживачі повинні пам'ятати про небезпеку торговельних операцій в нелегальній комерції, проте наразі це явище, швидше, $є$ невикорінним внаслідок ряду об'єктивнихісуб'єктивних причин.

Комерціалізація продукції в умовах стихійної торгівлі також базується на принципах взаємодії зі споживачами. Тут утворюються неформальні правила поведінки, які виникають тоді, коли не працюють правові норми. До основних принципів комерціалізації товарів в умовах стихійної торгівлі можна віднести:

1. Підтримку позитивної репутації продавця. Фактично, це є чи не єдиною гарантією для споживачів. У таких випадках взаємини грунтуються на довірі та позитивному досвіді. Крім цього, "вмикається" так зване сарафанне радіо, яке допомагає знаходити найбільш надійних продавців. Останні мають постійних клієнтів, інколи привозять продукцію на замовлення. Причому в деяких випадках попит може перевищувати пропозицію. Так, в умовах нелегального характеру торгівлі фрормуються неформальні норми взаємодії між учасниками ринкових відносин.

2. Вміння співпрацювати з конкурентами. Стихійна торгівля передбачає чи не найтіснішу взаємодію із суперниками, взаємну підтримку одне одного. Конфрлікти в такій ситуації, безумовно, трапляються, проте значно вигідніше співпрацювати з конкурентами, ніж напряму боротися з ними. Цьому сприяє готівковий характер торговельних операцій, коли продавці залежать одне від одного за потреби розрахунку зі споживачами. Можливо, непевність власного становища, а також ймовірність покарання також викликає відчуття солідарності. Конфрлікти можуть траплятися в умовах обмеженості простору для торгівлі або тоді, коли серед знайомих торговців з'являються новачки, які претендують на "закріплені" місця.

3. Встановлення гнучких, нефріксованих цін на продукцію. Частина продавців готова знижувати ціну на прохання потенційних споживачів. Можливість торгуватися є привабливою для деяких покупців. В окремих культурах торг перед покупкоює чи не обов'язковим атрибутом комерції. Продавці можуть змінювати ціну на свій розсуд залежно від того, хто купує їхню продукцію. У деяких випадках вони керуються не лише економічною необхідністю, але й етичними нормами та почуттям справедливості.

4. Сприйняття продукції на стихійних базарах як свіжої та натуральної. Безумовно, це не завжди так. Насправді, у цьому й полягає, на нашу думку, основний недолік такого типу торговельної діяльності. Продук- ція не проходить обов'язкової державної перевірки. Відповідно все залежить від сумлінності продавців і пильності споживачів. Дехто зі споживачів вважає, що товари на стихійних базарах дешевші, ніж у торговельних мережах, проте це не завжди так. Насправді, необхідно порівнювати кожну категорію продукції, причому ціни будуть відрізнятися на різних базарах.

5. Використання найпростіших маніпуляцій при здійсненні торговельних операцій. Серед найбільш поширених можна назвати ситуацію, коли продавець зважує більше товару, ніжпросив покупець, а потім запитує, чи можна залишити таку вагу. Багато покупців погоджуються на цю заміну. Пропозиція спробувати продукцію, зодного боку, є виправданою, а з другогобоку, змушує деякихспоживачів придбати товар через небажання образити продавця.

В умовах легальної торгівлі використовують більш широкий перелік інструментів комерціалізації результатів господарської діяльності. Зокрема традиційне стимулювання збуту продукції. За словами КарпенкоЮ.М., "...практика українського ринку свідчить, що виробники та торговці віддають перевагу простим заходам стимулювання покупки в торговельних точках" [3, с. 336]. Серед усіх заходів стимулювання збуту продукції найбільш успішними $\epsilon$ ті, які апелюють до допитливості споживача. Ті, кому вдається створити довкола товару ореол таємничості, можуть досягти значного успіху. Саме тому настільки популярними $є$ товари, в концепцію яких "введений" сюрприз. Це можуть бути солодощі, корм для тварин, продукти харчування, мийні засоби, всередині яких міститься подарунок. Як правило, такі акції тимчасові, хоча існують товари, для яких наявність додаткового презенту $є$ постійним атрибутом. Незважаючи на ефективність таких прийомів, варто бути обережними з деякими проявами стимулювання збуту. Наприклад, із сезонними акціями, коли подарунок або образ, який потрібно знайти, чітко асоціюється з порами року. Якщо акція не буде достатньо успішною, то пошук "зимових" речей навесні може лише закріпити негативний ефект. Цікаво, що таких помилок припускаються навіть відомі компанії.

До інструментів комерціалізації продукції в легальній торгівлі також належить так званий нейромаркетинг. За словами Гуменної О.В. та Гончарової К.О., "нейромаркетинг - одна з сучасних концепцій маркетингового впливу в роздрібній торгівлі, яка спирається на дослідження психології споживачів, що використовує технологію "сканування" мозку потенційних споживачів із метою визначити, на які образи цільова група реагує найбільш активно, і робить ставку на почуття та емоції клієнтів" [4, с. 38-39]. Якщо сорормулювати поняття "нейромаркетинг" більш просто, то він $€$ процесом вивчення поведінки потенційних споживачів під дією різних чинників, зокрема звуку (аудіомаркетинг), запаху (аромамаркетинг), кольору, емоційних образів, освітлення, шрифту тощо.

Використання звукового супроводу в комерційній діяльності може підвищувати або, навпаки, знижувати рівень попиту на продукцію. На нашу думку, варто дотримуватись певних правил аудіомаркетингу, зокрема: звуковий супровід повинен відповідати характеру товару чи концепції закладу. Наприклад, дорога продукція рекламується за допомогою вишуканої музики немасового характеру, яка викликає відчуття піднесення і зосередженості. Ще одним прави- 
лом є обмежене використання музики зі словами, оскільки останні можуть відволікати потенційного споживача. Крім того, варто обережно використовувати мінорний лад. Навряд чи останній підходить для здійснення комерційної діяльності, хоча, безумовно, бувають івинятки. Наприклад, дорогі рестораничи тематичні магазини.

Використання емоційних образів $є$ одним із найбільш доступних інструментів комерціалізації продукції. Проте частина власників комерційних закладів припускаються помилок, які, швидше, знижують рівень попиту на товари і послуги, ніж допомагають у їх реалізації. До основних прорахунків можна віднести нанесення додаткових зображень, які затуляють основну продукцію у залі, на вітрину крамниці. Як приклад можна навести квіткові магазини, де емоційні образи інколи "перебивають" сам товар, при цьому не поєднуються з ним. Також помилковим може бути використання абстрактних зображень. Останнє виступає суперечливим інструментом комерціалізації. Вони сприймаються складніше, ніж реалістичні образи. У потенційних споживачів може не бути часу довго роздумувати над значеннями абстрактних зображень, особливо в умовах, коли конкуренти пропонують щось зрозуміліше. На нашу думку, емоційні образи можуть бути універсальними та специфрічними. Наприклад, фото лабрадорапідходить для будь-якого зоомагазина чи ветеринарної клініки, а ось зображення шпіца доречне, швидше, для зоосалонів і не підійде для крамниць із зоотоварами.

Використання шрифтів у комерційній діяльності також відіграє досить важливу роль. Правильний підбір шрифрту може допомогти в реалізації продукції. Існує багато видів шрифтів, їх відбір для комерційної діяльності здійснюється на основі опитувань або інтуїції. Існують складні та прості для сприйняття шрифти, обидві групи мають переваги і недоліки. Прості шрифти легше сприймаються, краще підходять для зовнішньої реклами, частіше використовуються для офрормлення масової продукції. Водночас їм інколи не вистачає оригінальності та вишуканості. Складні шрифти, навпаки, частіше виступають атрибутом ексклюзивних товарів і послуг, підкреслюють творчий підхід до створення продукту, залишають більш яскраві враження. Проте у багатьох ситуаціях (для певних видів продукції, частково у зовнішній рекламі) використовувати їх недоречно.

Одним із найцікавіших інструментів комерціалізації продукції виступає реклама. Остання є одним із найбільш багатогранних і суперечливих суспільних френоменів. На думку Гребінь Н.В., "найяскравіший приклад свідомого маніпулювання - реклама" [5]. Реклама справді може містити елементи маніпуляції, проте так буває не завжди. Частина реклами носить суто інфрормативний характер, зокрема це більшою мірою стосується дешевших способів рекламування продукції. Частина сюжетної реклами або реклами, в якій використовується контрастний підхід, справді може містити елементи маніпуляцій. Проте на сьогодні багато рекламних повідомлень націлені на те, щоб потенційний споживач запам'ятав назву бренду. Водночас не обов'язково викликати углядача відчуття страху, огиди чи марнославства.

Інструментом комерціалізації в легальній торгівлі можуть виступати назви брендів і торговельних марок, які повинні відповідати не лише вимогам законодавства, але й маркетинговим нормам. Зокрема назви торговельних марок і брендів повинні легко читатися, запам'ято- вуватися і вимовлятися. Крім того, не можна забувати про прийнятний переклад назв марок на міжнародному ринку та доцільну кількість слів у назвах. Бренд чи торговельна марка повинні фрормувати потрібну виробнику асоціацію з товаром чи послугою. Наприклад, назви можуть "говорити" про розкіш, вишуканий смак, простоту, екологічність, патріотизм, мужність тощо. Важливо, щоб асоціація збігалась з концепцією продукту.

\section{ВИСНОВКИ}

Інструменти комерціалізації результатів господарської діяльності в законній та нерегульованій торгівлі частково збігаються, проте в легальній торговельній діяльності вони є більш складними та різноманітними. Незаконна торгівля передбачає вужчий спектр інструментів комерціалізації, оскільки поле для діяльності залишається дуже обмеженим. Проте за тривалий період учасники стихійної торгівлі виробили свої підходи до комерціалізації продукції, які носять неформальний характер і стали частиною суспільної культури.

\section{Література:}

1. Страшинська Л.В. Основніпринципи мерчандайзингу як способу стимулювання збуту продукції підприємств / Л.В. Страшинська / / Вісник Львівського національного університету ветеринарної медицини та біотехнологій імені Гжицького. - 2011. - № 13. - С. 286-291.

2. Свічкарь В.А. Партизанський та епатажний маркетинг як інноваційні прийоми просування товарів на ринку / В.А. Свічкарь, В.Ю. Чорномурова / / Ефективна економіки. - 2015. - № 2. - Режим доступу: www.economy.nayka.com ua

3. Карпенко Ю.М. Розвиток засобів стимулювання збуту в умовах сучасного ринку / Ю.М. Карпенко / / Науковий вісник Полісся. - 2016. - № 4 (8). - С. 335-339.

4. Гуменна О.В. Нейромаркетинг як інноваційний інструмент у маркетингу / О.В. Гуменна, К.О. Гончарова / / Наукові записки НаУКМА. - 2018. Т. 3. - № 1. - С. 38-44.

5. Гребінь Н.В. Зміст маніпуляції як різновиду прихованого психологічного впливу / Н.В. Гребінь / / Проблеми сучасної психології. - 2013. - № 21. - С. 80-93.

References:

1. Strashyns'ka, L.V. (2011), "Main principles of merchandising as a way of sales stimulation of production", Visnyk Lvivs'kohonatsional'noho universytetu veterenarnoii medytsyny ta biotehnolohii imeni Gzhyts'koho, vol. 13, pp. 286-291.

2. Svichkar', V.A. Chornomurova, V. lu. (2015), "Partisan and startling as innovative marketing techniques sales promotion", Efektyvna economica, vol.2, available at: http://www.economy.nayka.com.ua/?op=1\&z=3808 (Accessed 15 Jan 2020).

3. Karpenko, lu.M. (2016), "Development of goods promotion methods on the modern market", Naukovyi visnyk Polissya, vol. 4 (8), pp. 335-339.

4. Humenna, O.V. (2018), "Neuro marketing as an innovative instrument of marketing", Naukovi zapysky NaUKMA, vol. 3, no. 1, pp. 38-44.

5. Hrebin', N.V. (2013), "Essence of manipulation as a mean of hidden psychological influence", Problemy suchasnoi psyholohii, vol. 21, pp. 80-93.

Стаття надійшла до редакиї 03.02.2020 p. 